\title{
Strategies to Increase Universities' Scientific Publication in Indonesia
}

\author{
Ratna Komala Putri*, Kartika Wulandari, Irma Nilasari, Indra Taruna \\ Lecturer at Widyatama University, Bandung, Indonesia
}

Copyright $\bigcirc 2019$ by authors, all rights reserved. Authors agree that this article remains permanently open access under the terms of the Creative Commons Attribution License 4.0 International License

\begin{abstract}
Objective: The paper aims to seek strategies to improve the quality of universities' scientific publications in Indonesia. Design/ methodology/ approach: The present research uses both quantitative and qualitative approach to establish conceptual models and strategies to improve the quality of universities' scientific publications in Indonesia through hypotheses testing. Variables subjected to analysis include learning organizations, knowledge sharing, research climate, organizational/ institutional support, and quality of universities' scientific publications. Findings: Based on the empirical research results, it is found that there is significant relationship among learning organizations, research climate, knowledge sharing, institutional supports, and the quality of universities' scientific publications. Research limitations/implications: The research samples of 200 private universities were obtained from a minimum sample of studies using structural equation models. Practical implications: The findings of the study are beneficial for university management and lecturers in improving the quality of scientific publications; thus, improving the quality of Indonesian scientific publications to be the first rank in ASEAN region. Originality/ value: This research provides a meaningful contribution since there lack studies on strategies to improve the quality of scientific publications in Indonesia.
\end{abstract}

Keywords Learning Organizations, Research Climate, Institutional Support, Knowledge Sharing, Quality of University’s Scientific Publications

\section{Introduction}

The rapidly changing world requires universities in Indonesia to be able to improve the nation's competitiveness through the publication of educational research at the international level. International publications serve to enhance a country's self-image in the educational and scientific quality. Countries that have good quality in education, science and technology tend to have a high number of international publications. Moreover, Indonesia's 6th Nawacita agenda encompasses the integration of research activities of ministries with state institutions and universities which has led the country to reach second place in the number of scientific publications, outperforming Singapore and Thailand. Previously, Indonesia had published 5,299 articles in 2013 and almost four-fold in 2018 becoming 20,610 articles. The following graph presents the comparison of ASEAN countries in the number of international publications during the period of $2013-2018$.

Indonesia possesses a high opportunity to rank first at the ASEAN level since the country has a large number of tertiary educational institutions compared its counterparts in ASEAN region. The population of lecturers in Indonesia is also Indonesian's strength to reach the position. Therefore, lecturers and researchers in the country have also to be more prolific in producing quality scientific works, rather than merely increasing the number. As such, the Director General of Research Development, Ministry of Higher Education, Muhammad Dimyati (Media Indonesia Online, accessed on Thursday, 03 May 2018), stating that, although scientific publications have increased in terms of quantity, the scientific journals and academic results in Indonesia is still considered poor quality. Meanwhile, the quality of publication is indicated by the number of citations. Thus, the high citation index reflects the high quality of scientific publications.

Therefore, research on strategies to improve the quality of scientific publications in Indonesia is in immediate demand, so that the increase in the number of scientific publications at the ASEAN level is also simultaneous with the high quality of scientific publications. This can also have an impact on Indonesia's position at the global scale. Therefore, the study aimed to solve the problem pertaining to the poor quality of scientific publications of universities in Indonesia. By improving the conducive academic atmosphere in universities, institutions provide full support for research activities and scientific publications of lecturers as well as the high level of knowledge sharing 
behavior in universities leading to the increased quality of scientific publications of universities in Indonesia. By this strategy, Nawacita aspiring being the first rank at the ASEAN level in the scientific publications can be achieved.

\section{Literature Review}

\section{A. Learning Organization}

Learning organization is a form of those which always encourage and support continuous learning at every level in the organization so that it can adapt to a rapidly changing environment to improve organizational better capacity in the future. Learning starts from individuals who carry out the learning process in an organization. As expressed by Talikeh and Taliyeb (2013); Zhu, et.al (2017); Çalik, Çelik \& Sönmez (2018); Garaeva \& Ahmetzyanov, 2018, a learning organization relies on the learning process of individual within the organization;given such a fact, it is very important to understand individual learning processes to facilitate understanding of organizational learning.

The experts have almost similar opinion about learning organizations, to which they define as an organization which always encourages and supports continual learning process at every level in the organization in order to adapt to environmental changes. Furthermore, learning organizations are those which continuously develop their capacity to adapt to the changing environments (Robbin, 2009: 668); Yulisutiany, (2018). They are organizations, which have learning and adaptive capacity to improve change, as well as training processes carefully in harmony with company'sobjectives. (Noe, 2010: 202). It is the place where its members continually learn new things (Noe et al., 2010: 22). It is an organization, which is intentionally designed to build structure, culture, and strategy so that it can exchange and maximize the potential for organizational learning to take place in an exploratory and exploitative manner (Jones, 2010, 364). A learning organization is that which succeeds in acquiring, processing, and applying knowledge to be used to help adapt to change. (Greenberg, 2011: 604). At last, learning organizations are measured based on personal abilities, mental models, building shared vision, team learning and systematically thinking.

\section{B. Research Climate}

Climate is originally derived from the Greek word 'incline', which means not only limited to physical matters, such as temperature or pressure. It also has a psychological meaning that people who are members of an organization, live within the organization and interact to form a deep social system through which its development cannot be separated from environmental influences both external and internal environment. This means that besides having to live with changes in the environment that are sometimes unpredictable, members of the organization also have to deal with the changes that exist within the organization. Climate is a dynamic system concept, it cannot be touched and seen, but it can be felt.

A research is understood as a scientific method to obtain data, which has certain purposes and uses. Meanwhile, a scientific method means that the research activities are carried out based on scientific characteristics, such as rational, empirical, and systematic to achieve certain goals. Emzir (2007: 3) said that a research is an effort to find, develop, and test the truth of knowledge, which is carried out by scientific methods. Suryana (2010); Khan \& Mohammad (2018); Dampson \& Frempong (2018); Zheng, 2018 stated that research activities must take into account several values, such as emotional neutrality, universalism, openness, independence, whose strength lies in the argument. Therefore, the research climate is defined as the work atmosphere, attitude, and interaction of lecturers in finding, developing and testing the truth in a systematic, empirical, controlled, open and independent manner in the university environment. Climate research is measured based on research innovation, lecturer's research supervision, research resources and collaboration, as well as internationalization.

\section{Institutional Support}

Within organization, social interactions can occur in the context of individuals with their organizations. The study of institutional support obtained the concept of organizational support. Robbins \& Coulter (2009:303) argued that organizational support is perceived as a common belief of employees that the organization in which they join or work respects their contributions and cares for them. Meanwhile, Bilgin \& Demirer (2012); Likitrattanaporn (2018) suggested that organizational support the employees can perceive is meaningful and beneficial to meet their social-emotional needs. The organizational support can also be in form of supervisory activities, such as employee counseling, challenging assignments for employees, employee protection, employee coaching, ensuring harmonious relationships among employees and role modeling (Baranik et al., 2010; Tarusikirwa 2017). In her previous study, Ratna (2018); Udeani \& Kayode (2018), more specifically, defined organizational support for a university, which is the extent to which universities provide support and assistance when needed, respect for contributions, care for social-emotional needs, well-being, relationships and feelings of mutual assistance among lecturers and leaders. Thus, it was obtained a construct regarding the supports of higher educational institutions, which are those received by lecturers in the form of training, resources provision, care 
for what lecturers need, and availability of sufficient time to complete tasks. Institutional support is measured through scientific publication training, financial support and providing time for conference.

\section{Knowledge Sharing Behavior}

Srivasta et al. (2006); Manaf \& Ibrahim (2017) argued that knowledge sharing is vital because it is the key which allows codification and storage of achieved knowledge, so that it can be developed over time. In order that it can be developed into a competitive advantage, the knowledge must be shared. On the other hand, Adenan et al. (2013: 338) stated that knowledge sharing is a process of exchange and obtaining the necessary knowledge through both formal and informal methods. However, Ivancevich (2014: 6) only argued that knowledge sharing is a salient aspect of competition. Meanwhile, Mc. Shane (2015: 11) added that knowledge sharing involves the dissemination of knowledge to others within the organization. For instance, with intranet network and digital repositories, knowledge sharing takes place through structured and informal communication, as well as in various forms of learning.

Based on the results of previous studies, knowledge sharing can be in forms of activities of transferring, developing, stimulating creation, protecting and facilitating the dissemination of information, ideas, suggestions and expertise in universities both formally and informally (Ratna, 2018; Durak \& Çankaya 2018). Hence, a new construct for knowledge sharing in universities is obtained, i.e. the activity of transferring, developing, stimulating creation, protecting and facilitating dissemination of information, ideas, suggestions and expertise in higher educational institutions. Therefore, knowledge sharing is measured based on activities, organizations, people and technology.

\section{E. Quality of Scientific Publication}

The construct, which pertains to the quality of scientific publications was conceptualized from the aspect of performance as proposed by Stone (2008: 36) who argued that performance is related to particular achievement indicated by work completion. In addition, Bernardin (2010: 222) defined that performance is a record of results derived from the function of certain work activities during a specified period of time.

In higher education, the measure of the success of institutional performance is greatly dependent on the lecturer's performance in carrying out their duties and responsibilities. It is because that based on the Law of the Republic of Indonesia Number 14 of 2005 concerning Teachers and Lecturers Article 1 paragraph 2, lecturers are defined as professional educators and scientists whose the main tasks are transforming, developing, and disseminating science, technology, and art through education, research, and service to the community. More specifically, based on the results of previous studies, the performance of scientific publications is measured through both the aspect of quantity and quality of results, the timeliness in realization of objectives, vision and mission of the university in scientific publications (Ratna: 2018). Yet, in this study, it is found a construct that the quality of scientific publications is a dynamic condition regarding the process, results, and usefulness of scientific publications because it is more specific to the quality of scientific publications, which is measured based on topic novelty, systematics, literatures, grammar and usefulness.

\section{Methodology}

The research used both quantitative and qualitative approachesto find a conceptual model for improving the quality of scientific publications of universities in Indonesia through hypothesis testing. Meanwhile, the population in the study was private universities in Indonesia, which accounted for 432 institutions, from which, the research samples were obtained as many as 200 private universities based on a representative sample size of a large population using structural equation models. In addition, there were some variables to be observed, such as learning organizations, knowledge sharing, research climate, institutional support, and quality of scientific publications in the universities.

\section{Results and Discussion}

The hypotheses testing was carried out both simultaneously and partially for the influence of learning organizations, research climate, institutional support, and knowledge sharing on the quality of scientific publications of universities in Indonesia.

\section{A. Simultaneous Hypotheses Testing}

This section will explain the results of simultaneous hypothesis testing regarding the influence of learning organizations, researchclimate, institutional support, knowledge sharing on the quality of scientific publication of private universities in Indonesia.

Table 1. Simultaneous hypotheses testing

\begin{tabular}{|c|c|c|}
\hline Hypotheses & $\mathrm{R}^{2}$ & F count \\
\hline $\begin{array}{c}\text { Learning organization, research } \\
\text { climate, institutional support, } \\
\text { knowledge sharing on the quality of } \\
\text { scientific publications }\end{array}$ & 0.74 & $278.35^{*}$ \\
\hline
\end{tabular}

* Significant at the level of $\alpha=0.05$ (F table $=3.04$ )

Based on the test results as seen in the table above, it is found that at $95 \%$ confidence level $(\alpha=0.05)$,there are 
simultaneous influences of learning organizations, research climate, institutional support, and knowledge sharing on the quality of scientific publications, where the influence of the two variables is $74 \%$ while the remaining $26 \%$ is influenced by other factors not investigated in this study.

\section{B. Partial Hypotheses Testing}

The following section will explain the results of partial hypothesis testing, i.e. the influence of learning organizations, research climate, institutional support, and knowledge sharing on the quality of scientific publication.

Table 2. Partial hypothesis testing

\begin{tabular}{|c|c|c|c|}
\hline Hypothesis & $\gamma$ & $\mathrm{R}^{2}$ & $\mathrm{~T}$ count \\
\hline $\begin{array}{c}\text { Learning organization } \rightarrow \text { quality of } \\
\text { scientific publications }\end{array}$ & 0.48 & 0.22 & $3.50^{*}$ \\
\hline $\begin{array}{c}\text { Research climate } \rightarrow \text { quality of } \\
\text { scientific publications }\end{array}$ & 0.42 & 0.19 & $2.66^{*}$ \\
\hline $\begin{array}{c}\text { Institutional support } \rightarrow \text { quality of } \\
\text { scientific publications }\end{array}$ & 0.35 & 0.13 & $2.21^{*}$ \\
\hline $\begin{array}{c}\text { Knowledge sharing } \rightarrow \text { quality of } \\
\text { scientific publications }\end{array}$ & 0.50 & 0.20 & $2.87^{*}$ \\
\hline
\end{tabular}

* Significant at $\alpha=0.05$ (t table $=1.96$ )

In the table above, it can be observed that partially, variable of learning organization, research climate, institutional support and knowledge sharing has significant results since the value of t count is greater than that of $t$ table. In addition, the inner coefficient value $(\gamma)$ is also positive. From the table above, all variables have an influence on improving the quality of scientific publications.

Learning organizations have an influence by $22 \%$ in improving the quality of scientific publications. When improving the lecturers' personal competencies in writing scientific papers, building strong mental models and shared visions, conducting team learning and systematic thinking; the quality of university scientific publications will be improved.

The research climate has an effect by $19 \%$ in improving the quality of scientific publications. It can be realized if lecturers innovate in their research, leaders supervise research activities the lecturers carry out, there are availability of sufficient resources for researches, researchers always conducts research collaboration with domestic universities both private and state universities as well as other institutions; and they internationalize their researches. By such strategies, then they are able to enhance the quality of university scientific publications.

Meanwhile, institutional support has an effect by 13\% in improving the quality of scientific publications. Thus, if the institution organizes scientific publication training for lecturers, provides funding support for research activities and lecturers' scientific publications, and gives lecturers the opportunity to attend conferences, the quality of university scientific publications will improve.

Knowledge sharing poses the influence by $20 \%$ in improving the quality of scientific publications, sharing activities ranges from publishing scientific articles and sharing scientific articles and experiences at conferences to participating in conferences. To university context, it could be expanding the workshop on writing scientific articles, seminars on the results of lecturer's research, mentoring lecturers' research, supporting IPR (intellectual property right) registration, providing incentives, and conducting research forums. The university always maintains an updated website and e-mail available integrated with the site has a database of lecturer research, and provides software for data analysis as well as research lecturer repository. It also has to motivate the implementation of scientific discussions among lecturers, helping each other in conducting research and sharing information and feedback in research.

Based on the results of the study, a strategy model for improving the quality of scientific publications of universities in Indonesia is presented in Figure 1 as follows.

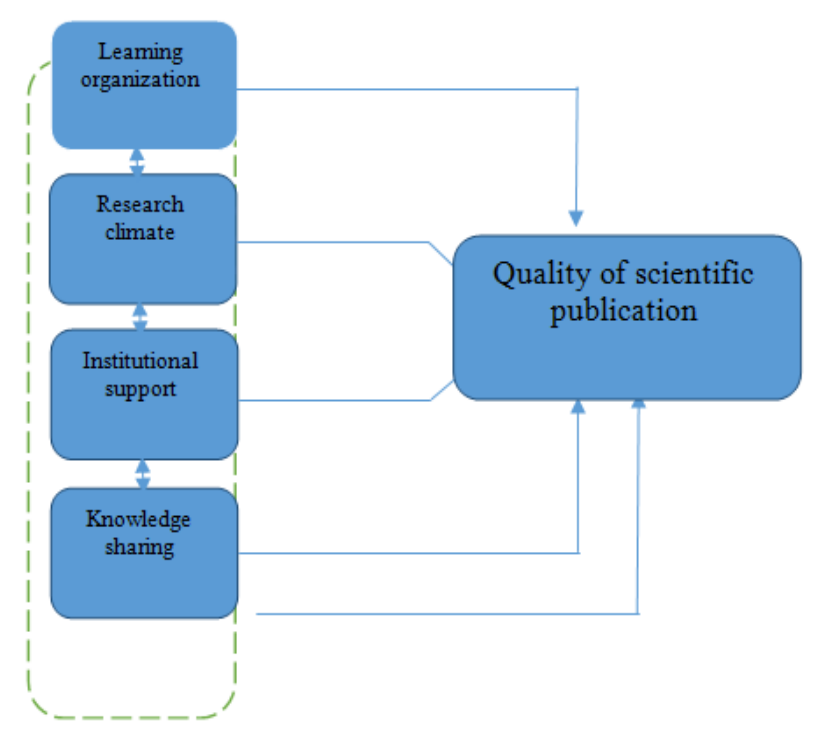

Figure 1. Model of strategy to improve quality of scientific publication

The model can offer a solution for universities in Indonesia in taking strategic direction to improve the quality of scientific publications in Indonesia, among others:

- $\quad$ Systematics of written articles to be published according to the standards of particular journal;

- The excellent quality of grammar contained in articles published at the international level;

- The high value of novelty in topics of articles to be published in international journals;

- A high citations index of articles published by Indonesian universities contained in international journals.

- The usefulness of articles for the improvement of both local and global civilizations.

Therefore, Indonesian scientific publications can occupy the first position in ASEAN and can compete globally in 
the scientific publications. Eventually, it is expected that Indonesian scientific publications can reach the top ten at the global level.

\section{Conclusions}

Indonesia possesses a high opportunity to excel in scientific publications at the ASEAN level. Furthermore, it can be realized provided that the university embodies a continuous learning organization to advance its competitiveness in scientific publications, create a conducive research climate, provide firm support for lecturers' scientific publications and propagate knowledge sharing behavior, which eventually can enhance the quality of university's scientific publications.

\section{REFERENCES}

[1] Bernardin, Jhon. 2010. Human Resource Management. An Experiential Approach. International Edition. Published by Mc. Graw-Hill Companies, Inc., 1221. Avenue of the Americas, New York.

[2] Çalik, F., Çelik, I., \& Sönmez, S. (2018). The Investigation of Competence of Teachers and Kindergartens in Terms of Movement Education Achievements in Pre-School Education Program. Journal of Education and e-Learning Research, 5(3), 179-184.

[3] Dampson, D. G., \& Frempong, E. A. (2018). The 'Push and Pull' Factors of Distributed Leadership: Exploring Views of Headteachers across Two Countries. Asian Journal of Education and Training, 4(2), 121-127.

[4] Dessler, Gary. 2010. Manajemen Sumber Daya Manusia. Terjemahan Paramita Rahayu. Jakarta: Penerbit PT Indeks.

[5] Durak, G., \& Çankaya, S. (2018). Seamless Learning: A Scoping Systematic Review Study. Journal of Education and E-Learning Research, 5(4), 225-234.

[6] Garaeva, A. K., \& Ahmetzyanov, I. G. (2018). Awareness of Historical Background as One of the Factors of Better Language Acquisition. International Journal of English Language and Literature Studies, 7(1), 15-21.

[7] Greenberg, Jerald. 2011. Behaviour in Organizations. Tenth Editions. Published by Person education publishing as Prentice Hall. United States.

[8] Jones, Gareth. 2010. Organizational Theory, Design and change. Sixth Edition. By Pearson Education, Inc. New Jersey.

[9] Khan, A., \& Mohammad, J. (2018). Current Practices in Higher Education Institutes Pakistan and Gap Reduction between Industry and Academia: A Systematic Literature Review Approach. Asian Journal of Contemporary Education, 2(2), 173-181.

[10] Larissa and Makela. 2009. Organizational Climate and Knowledge Sharing: An Individual-Level Perspective.
Paper to be presented at the Summer Conference 2009. On CBS - Copenhagen Business School Solbjerg Plads 3 DK2000 Frederiksberg DENMARK, June 17 - 19.

[11] Likitrattanaporn, W. (2018). A Study of Language Learning Strategies for Practical Use through the Process of Cooperative Learning. International Journal of Educational Technology and Learning, 3(1), 35-44.

[12] Luthans, Fred. 2011. Organizational Behavior. International edition. Publish By. Mc. Graw-Hill/Irwin. North America

[13] Manaf, N. A., \& Ibrahim, K. (2017). Poverty reduction for sustainable development: Malaysia's evidence-based solutions. Global Journal of Social Sciences Studies, 3(1), 29-42.

[14] Marko Slavkovic and Verica. 2013. Knowledge Management, Innovativeness, and Organizational Performance: Evidence from Serbia. Economic Annals, Volume LVIII, No. 199, Udc: 3.33 ISSN: 0013-3264

[15] Massingham, Peter \& Diment. 20 Organizational Commitment, Knowledge Management Interventions, and Learning Organization Capacity. The Learning Organization. Vol. 16 No. 2. pp. 122-142 .Emerald Group Publishing Limited.

[16] Mathis, R \& Jackson, J. 2011. Human Resource Management. Terjemahan Diana Angelica. Jakarta: Penerbit Salemba Empat.

[17] Mc Shane, Glinow, Von. 2010. Organizational Behavior. Fifth Editions. United States.

[18] Patnaik, B. \& Beriha, G.S. 2013. Organizational Learning in Educational Settings (Technical): An Indian Perspective. The Learning Organization. Vol. 20 No. 2, pp. 153-172. Emerald Group Publishing Limited.

[19] Raymond A. Noe. 2010. Employee Training and Development. Fifth Edition. Exclusive rights by McGraw-Hill Educational. North American Version.

[20] Raymond J. Stone. 2008. Human Resource Management, sixth edition. Published by John Wiley \& Sons Australia, Ltd.

[21] Robbins, Stephen P. Timothy A Judge. 2011. Organizational Behavior. Fourteenth Edition. Published by Pearson Education, Publishing as Prentice Hill.

[22] Robert N. Luissier. 2008. Human Relations in organizations: Applications and skill building. Seventh Editions. Publish McGraw-Hill \&Companies, Inc. Americas

[23] Salim, Islam Mohamed \& Mohamed Sulaiman. 2011. Organizational Learning, Innovation and Performance: A Study of Malaysian Small and Medium Sized Enterprises. International Journal of Business and Management Vol. 6 , No. 12. Emerald Group Publishing Limited.

[24] Senge, Peter. 2004. The Fifth Discipline. E-books.

[25] Som; Yeow, Roland; Wahab, Sazali. 2012. The Implementation of Learning Organization Elements and Their Impact towards Organizational Performance amongst NPOs in Singapore. International Journal of Business and Management. Vol. 7. No. 12. pp. 2-35. 
[26] Tarusikirwa, M. C. (2017). Understanding the Barriers to Collaborative Research: Experiences of Some Academics at the Zimbabwe Open University. American Journal of Education and Learning, 2(2), 132-139.

[27] Tineh, Abu. 2011. Exploring the Relationship between Organizational Learning and Career Resilience among Faculty Members at Qatar University. International Journal of Educational Management. Vol. 25 No. 6. pp. 635-650. Emerald Group Publishing Limited.

[28] Udeani, N., \& Kayode, F. (2018). Evaluation of the Goals of Art Education Programme in the North-East, Nigeria. International Journal of Education and Practice, 6(2), 76-83.

[29] Ungku Ahmad, Ungku Norulkamar. 2014. A review of knowledge sharing barriers among academic staff - a Malaysian perspective. Sains Humanika, 2 (2). pp. 87-91. ISSN 2289-6996

[30] Xiaoqingdan Joanne. 2014. Knowledge sharing in ChinaUK Higher Education alliances. International Business Review.

[31] Yulisutiany, I. (2018). Study of Education Competency and Effect on Learning Process of BCCT Method on Educational Group of Education Age (PAUD) in Sukasari Bandung. International Journal of Educational Technology and Learning, 3(2), 69-77.

[32] Zheng, J. (2018). The Incorporation of Subject Knowledge in Teaching Scientific Translation. International Journal of English Language and Literature Studies, 7(2), 45-49.

[33] Zhu, M., Yang, Z., Qu, Z., \& Wang, T. (2017). The Study on Training of University New Teachers in China. American Journal of Education and Learning, 2(2), 140-147. 